\title{
Beta-cell growth in the neonatal Goto-Kakisaki rat and regeneration after treatment with streptozotocin at birth
}

\author{
J. Movassat, B. Portha \\ Laboratory Physiopathology of Nutrition, University Paris/D. Diderot, CNRS ESA 7059, Paris, France
}

\begin{abstract}
Aims/hypothesis. In the Goto-Kakisaki rat, a genetic model of non-insulin dependent diabetes, we have recently reported that as early as fetal age, there is a restriction of the beta-cell mass which is maintained in the adult animal and is detectable before the onset of hyperglycaemia. It is therefore important to investigate the beta-cell growth potential in young GotoKakisaki rats.

Methods. We have studied in 4 and 7-day-old GotoKakisaki neonates: 1 . the in vivo replication rate of the beta cell; 2 . the occurrence of beta-cell apoptosis; 3 . the effectiveness of beta-cell regeneration after damage caused by neonatal treatment with streptozotocin.

Results. The replication rate in vivo of beta cells and the beta-cell apoptosis were similar in untreated Wistar and Goto-Kakisaki neonates on days 4 and 7 whereas the total beta-cell masses were reduced to $50 \%$ in the Goto-Kakisaki groups. Treatment with streptozotocin reduced the total beta-cell mass to the same extent in both Wistar and Goto-Kakisaki rats on day 4 compared with the corresponding nor-
\end{abstract}

mal values in Wistar and Goto-Kakisaki neonates. From day 4 to day 7, spontaneous beta-cell regeneration was manifest in both groups. Compared with the Wistar streptozotocin group, the net value of the beta-cell mass added during this period was more limited in the Goto-Kakisaki streptozotocin group, despite the replication activity of the residual beta cells being increased in this group to the same extent as in the Wistar streptozotocin group.

Conclusion/interpretation. We therefore suggest: 1. that the reduced beta-cell mass in the untreated neonatal Goto-Kakisaki rat does not appear to reflect a reduction in the rate of beta-cell replication or an increased beta-cell death by apoptosis but is potentially due to an impaired rate of beta-cell neogenesis, and 2 . that beta-cell regeneration can be reactivated after streptozotocin insult in the neonatal Goto-Kakisaki rat, although to a lesser extent compared with that in streptozotocin-treated Wistar neonates. [Diabetologia (1999) 42: 1098-1106]

Keywords Regeneration, neogenesis, beta-cell proliferation, beta-cell apoptosis, GK rat, Type II diabetes.
Received: 8 January 1999 and in revised form: 26 February 1999

Corresponding author: Professor B. Portha, Lab. Physiopathology of Nutrition, CNRS ESA 7059, Université Paris 7/D. Diderot, 2 place Jussieu, F-75251 Paris Cedex 05, France Abbreviations: GK, Goto-Kakisaki; W, Wistar; n0-STZ, streptozotocin administration at birth; BrdU, 5 '-bromo-2'-deoxyuridine; TdT, terminal deoxynucleotidyl transferase.
Established Type II (non-insulin-dependent) diabetes mellitus is associated with profound insulin secretory defects that occur together with insulin resistance. The basis for the insulin secretory defects is not known and is difficult to study in human subjects because it is not possible to identify prospectively those subjects in whom glucose control will deteriorate. That total beta-cell mass is decreased in Type II diabetic patients compared with control subjects matched with them for weight [1] offers strong support for the notion that insulin production may become in- 
sufficient if beta-cell growth is deficient. In such a perspective a failure to maintain sufficient functional beta-cell mass could play a major part in the pathogenesis of Type II diabetes.

Among the rodent models of Type II diabetes, the Goto-Kakisaki (GK) rat, which is a spontaneous model is a suitable one for the study of the relation between changes in beta-cell mass and the occurrence of non-insulin-dependent diabetes. We have recently reported in the GK rat, that as early as at the fetal age, there is a reduction of beta-cell mass which is maintained throughout adult life [2]. This defect clearly predates the onset of diabetes (basal hyperglycaemia) which was detectable 3 weeks after birth. During normal pancreas development, new beta-cells can be formed either by replication of pre-existing differentiated beta cells or by neogenesis, i. e. differentiation from stem cells [3-5] and the loss of beta cells in the neonatal pancreas can occur by progammed cell death or apoptosis [6]. In order to investigate the beta-cell growth potential in the GK model, we have studied the in vivo rates of beta-cell apoptosis and replication in 4-day-old and 7-day-old untreated neonates. In addition, we studied the efficiency of beta-cell regeneration after damage caused by neonatal treatment with streptozotocin (STZ), because this is a suitable procedure for evaluating the regeneration potential of beta cells in neonatal rats [7-10].

\section{Materials and methods}

Animals. Diabetic GK rats were obtained from our local colony initiated in Paris in 1988 [11] with progenitors issued from the original colony established elsewhere [12]. Wistar and GK rats were fed ad libitum with pelleted chow (UAR, ref 113, Villemoisson-sur Orge, France). Females from each strain were caged with a male from the homologous strain for one night and pregnancy was detected by abdominal palpation 14 days later. Natural birth occured 22 days after mating.

Four experimental groups of rats were studied: 1 and 2; control Wistar (W) and GK groups in which newborn rats received a single intraperitoneal injection of citrate buffer $(\mathrm{pH}$ 4.5) after their birth (day 1$) ; 3$; W/n0-STZ group in which rats on the day of their birth (within $10 \mathrm{~h}$ after delivery) received a single intraperitoneal injection of $100 \mu \mathrm{g} / \mathrm{g}$ body weight of streptozotocin (Sigma, St Quentin-Fallavier, France) freshly dissolved in citrate buffer; 4; GK/n0-STZ group: GK rats received the same treatment as Wistar rats.

In each group, the pups were left with their own mothers and kept in an environment of constant temperature, humidity and day-night cycle. The number of animal per litter was kept at eight. All the neonates from groups 3 and 4 were tested on day 2 for glycosuria with Clinistix (Bayer Diagnostics, $\mathrm{Pu}$ teaux, France). Wistar/n0-STZ and GK/n0-STZ animals were included in the study only if they were glycosuric $(3+$ value with the Clinistix test) on day 2 after birth. Pups were killed by decapitation 4 or 7 days after birth. Blood samples were collected after decapitation and immediately centrifuged at $4{ }^{\circ} \mathrm{C}$.

In each group, 4 to 20 animals were studied. The pancreases from 4 to 16 pups were cut at random into two size-equivalent pieces: one piece was stored at $-20^{\circ} \mathrm{C}$ and used for the mea- surement of insulin content and the other was fixed in aqueous Bouin's solution for $24 \mathrm{~h}$, embedded in paraplast and used for measurement of beta-cell mass.

Immunohistochemistry and morphometry. Each pancreatic block was serially sectionned $(7 \mu \mathrm{m})$ throughout its lenght to avoid any bias due to regional changes in islet distribution and islet cell composition, and then mounted on slides. Adjacent sections at a fixed interval throughout the block (every 35 th section) were immunostained for insulin and glucagon using a technique adapted from peroxidase indirect labelling, as described previously [13]. Anti-insulin serum purchased from ICN (ref. 65-104-1, ICN Pharmaceutical, Orsay, France) was raised in guinea-pigs against porcine insulin. Labelling was by a peroxidase-conjugated rabbit anti-guinea-pig IgG (Dako, ref. PO141, Trappes, France). The activity of the peroxidase complex was seen with 3,3'-diaminobenzidine-tetra hydrochloride using a peroxidase substrate kit DAB (Biosys-Vector, Compiègne, France). For immunostaining of glucagon, antiglucagon serum (ICN, ref 64-706-1), raised in rabbit and peroxidase-conjugated goat anti-rabbit IgG (ref. 074-15-06 KPLDynatech, St Quentin en Yvelines, France). Nuclei were stained with haematoxylin. After staining, sections were mounted in Eukitt (Labonord, Templemars, France).

A computer assisted image analysis based on an Olympus $\mathrm{BH} 2$ microscope connected via a colour video camera to a Compac PC computer and Imagenia 1000 software (Biocom, Les Ulis, France) was used to evaluate measurements. The area of insulin positive cells, as well as that of total pancreatic sections was evaluated in each stained section. Beta-cell relative volume was determined according to stereological methods by calculating the ratio between the area occupied by immunoreactive cells and that occupied by total pancreatic cells. Total beta-cell mass per pancreas was derived by multiplying the total pancreatic weight by the beta-cell relative volume.

To estimate the number of the duct-associated beta cells in each group at day 7 after birth, we scored in three to six sections per pancreas, (three animals per group) both the number of single beta cells and the number of beta-cell clusters which were incorporated into the duct epithelium or were in close contact with the ducts. The results were expressed for each compartment, as the number of single beta-cells or beta-cell clusters, per 100 duct cells present in each pancreas.

Beta-cell replication. For replication studies, three to four animals in each group were injected $1 \mathrm{~h}$ before decapitation with 5 '-bromo-2'-deoxyuridine (BrdU) (Sigma, St Quentin-Fallavier, France) at a dose of $50 \mathrm{mg} / \mathrm{kg}$ i.p. body weight. After decapitation the pancreas was dissected, weighed, fixed and embedded as described previously. We cut $6 \mu \mathrm{m}$ serial sections. Sections were double stained for BrdU and for insulin. We used a cell proliferation kit (Amersham, Les Ulis, France) for immunostaining for BrdU. Briefly, sections were incubated with a mixture of nuclease and mouse monoclonal anti-BrdU antibody $1 \mathrm{~h}$ at room temperature, washed with TRIS- $\mathrm{HCl}$ $(\mathrm{pH} 7.6)$, incubated with a peroxidase anti-mouse immunoglobulin $\mathrm{G}$ ( $\mathrm{IgG} 2$ ) for $30 \mathrm{~min}$ and stained with 3,3'-diaminobenzidine tetrahydrochloride using a peroxidase substrate kit (Biosys-Vector). After BrdU labelling, the tissue sections were washed in TRIS- $\mathrm{HCl}$ and then the same sections were stained for insulin. Insulin staining was by a guinea pig polyclonal anti-insulin antibody (ICN). This antibody was labelled with a goat anti-guinea-pig alkalin phosphatase-conjugated antibody (ref SBA 6090-04, Sera-Lab, Crawley-Down, England). It was revealed with alkalin phosphatase substrate kit I (Vector). In these double stained sections, beta cells exhibited red cytosol and BrdU-positive cells, brown nuclei. To estimate the 
beta-cell replication rate, beta cells and BrdU-positive beta cells were counted using an Olympus BX40 microscope (Olypus-France, Rungis, France). Results were expressed as the percentage of BrdU-positive beta cells. For each pancreas 500 to 2000 beta cells were counted.

Beta-cell apoptosis. The pieces of pancreas from 4 and 7-dayold Wistar and GK neonates were fixed in an immersion of $4 \%$ paraformaldehyde in PBS for $24 \mathrm{~h}$ and then processed and embedded in paraplast using standard histological techniques. Serial sections of $5 \mu \mathrm{m}$ were then cut.

An in place Apoptosis Detection Kit (Apoptag Plus Peroxidase, ref. S7101-KIT) (Oncor Appligen, Illkrich, France) in which residues of digoxigenin-nucleotide are catalytically added to 3 '-OH ends of DNA by terminal deoxynucleotidyl transferase $(\mathrm{TdT})$ was used. The anti-digoxigenin antibody carries a conjugated reporter enzyme (peroxidase) to the reaction site. As a positive control, we used sections of rat mammary glands provided with the kit. The omission of terminal deoxynucleotidyl transferase during the labelling procedure provided a negative control. The labelling procedure was as follows: the slides were deparaffinized in two changes of xylen for 5 min each wash and rehydrated in successive baths of absolute ethanol for $5 \mathrm{~min}$ and $95 \%$ and $70 \%$ ethanol for $3 \mathrm{~min}$ and washed in PBS three times for $5 \mathrm{~min}$. Then sections were incubated with $5 \mu \mathrm{g} / \mathrm{ml}$ proteinase $\mathrm{K}$ (Boerhinger Mannheim, Meylan, France) for $15 \mathrm{~min}$ at room temperature and washed in four changes of distilled water ( 2 min each wash). The endogenous peroxidase was quenched in $3 \%$ hydrogen peroxide in PBS for $5 \mathrm{~min}$ and then slides were rinsed in three changes of PBS for $5 \mathrm{~min}$ each. The equilibration buffer was then applied on sections and covered by a plastic coverslip and incubated for 1 to $2 \mathrm{~min}$.

After removing the coverslips and excess liquid, the solution containing the reaction buffer and TdT enzyme was applied on sections, covered by plastic coverslips and incubated in a humidified chamber at $37^{\circ} \mathrm{C}$ for $1 \mathrm{~h}$. The slides were then placed in a coplin jar containing the working strength stop/wash buffer, agitated briefly and incubated for $10 \mathrm{~min}$ at room temperature. The slides were then washed in three changes of PBS for 5 min each wash and incubated with antidigoxigenin-peroxidase, covered by plastic coverslips and left in a humidified chamber for $30 \mathrm{~min}$ at room temperature. The slides were then rinsed in four changes of PBS for $5 \mathrm{~min}$ each and the activity of peroxidase was revealed using a DAB substrate kit (Biosys-Vector). The sections were then rinsed in PBS and stained for insulin as described before. After staining, sections were mounted in Eukitt. In each group, three to five sections and 1000 to 2000 cells were counted per pancreas. The cells were considered as apoptotic when the two following conditions were associated: nuclei stained with DAB after the TUNEL procedure; morphological features such as decreased cell volume together with nuclear shrinkage and chromatin condensation around the nuclear perimeter [14].

Individual beta-cell area. Beta-cell size was determined on sections stained with insulin by evaluating the mean cross-sectional area of individual beta cells. The beta-cell nuclei on a random section were counted and the area of beta-cell tissue in that section, measured by planimetry as described before. The beta-cell area was divided by the number of nuclei to calculate the area of each beta cell. Using this technique it must be recognized that the actual number of beta-cells is probably higher than the number counted because not all beta cells are sectioned across their nuclei and therefore the size of the beta cells is overestimated [15].
Analytical techniques. Plasma glucose was determined with a glucose analyser (Beckman, Gagny, France). Pancreatic insulin content was determined by radioimmunoassay. After excision, pancreases were weighed, homogenized and centrifuged at $4{ }^{\circ} \mathrm{C}$ in an acid-alcohol solution $(75 \%$ ethanol: $1.5 \% \mathrm{HCl} 12$ $\mathrm{N}: 23.5 \%$ distilled water). The supernatant was stored at $-20^{\circ} \mathrm{C}$. Pancreatic immunoreactive insulin was estimated using purified rat insulin as a standard (Novo-Nordisk, Copenhagen, Denmark) and antibodies to mixed (porcine and bovine) insulin and porcine ${ }^{125}$ I-monoiodinated insulin (Sorin Diagnostics, Antony, France) as tracer. Charcoal was used to separate free hormone from bound hormone. This method allows the determination of $0.1 \mathrm{ng} / \mathrm{ml}$ with coefficients of variation within and between assays of $10 \%$.

Statistical analysis. Values are expressed as means \pm SEM. For comparison between two groups, differences were evaluated using Student's unpaired $t$ test. A $p$ value less than 0.05 was considered significant.

\section{Results}

Characteristics of the 4-day-old GK/nO-STZ and W/ n0-STZ rats. The comparison of the characteristics between untreated Wistar and GK groups showed that GK newborns exhibited lower body weights and lower basal plasma insulin concentrations than the Wistar newborns at the same age but their basal plasma glucose concentrations were similar (Table 1). These data are in line with those we reported previously [2].

After treatment with STZ, the 4-day-old W/n0STZ and GK/n0-STZ neonates were of lower body weight than the corresponding untreated groups $(p<0.001$ and $p<0.05$, respectively). The plasma insulin concentrations of $\mathrm{W} / \mathrm{n} 0-\mathrm{STZ}$ rats were sharply decreased compared with untreated Wistar rats $(p<0.01)$ but the GK/n0-STZ neonates had similar plasma insulin concentrations than the GK neonates (Table 1).

The 4-day-old W/n0-STZ and GK/n0-STZ rats had higher basal plasma glucose concentrations than untreated Wistar and GK rats at the same age. It is remarkable that the hyperglycaemia was less severe in $\mathrm{GK} / \mathrm{n} 0-\mathrm{STZ}$ rats than in $\mathrm{W} / \mathrm{n} 0-\mathrm{STZ}$ rats (Table 1 ).

Light microscopy examination of the pancreatic sections in the 4-day-old $\mathrm{W} / \mathrm{n} 0-\mathrm{STZ}$ and GK/n0-STZ newborns showed a severe reduction in insulin-immunoreactive cells in the areas which, according to their arrangement of alpha cells (glucagon-immunostaining, data not shown) corresponded to pancreatic islets. Large or middle sized areas of beta cells were never observed in these two groups. In both groups, many of the surviving beta cells appeared to be partially degranulated. Another type of islet, being formed by a beta-cell cluster closely associated with the ductular epithelium, was also detectable in newborn rats. Such "beta-cell buds" were found both in $\mathrm{W} / \mathrm{n} 0-\mathrm{STZ}$ and GK/n0-STZ pancreases as well as in untreated Wistar and GK pancreases. 
Table 1. Body weight, pancreas weight and plasma glucose and insulin concentrations in 4 or 7-day-old Wistar, W/n0-STZ, GK and GK/n0-STZ neonates

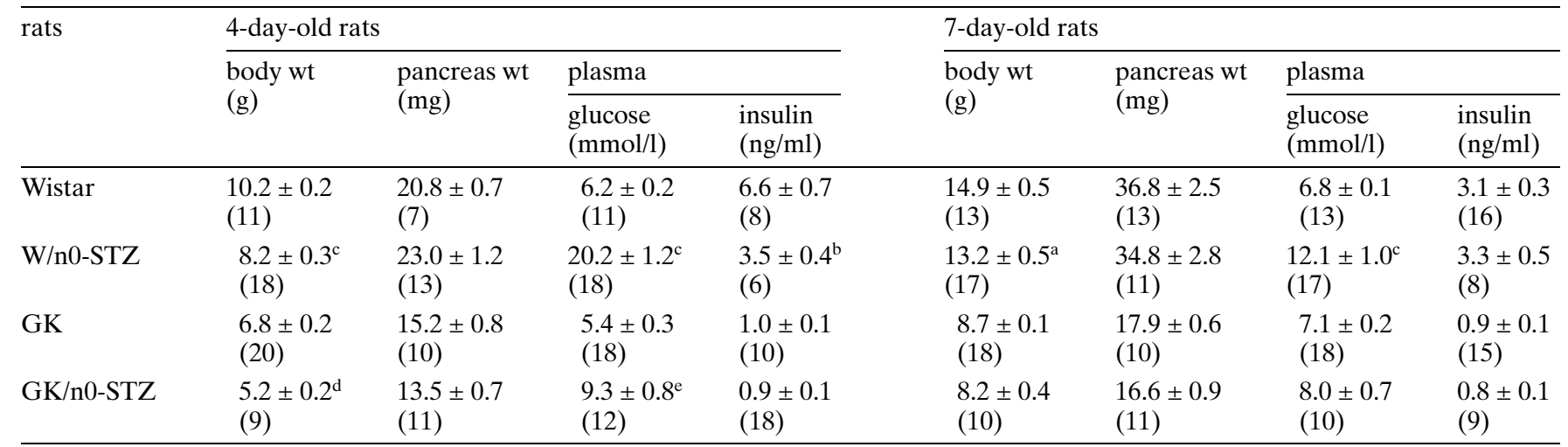

Values are expressed as means \pm SEM. The number of animals $\quad{ }^{\mathrm{a}} p<0.05 ;{ }^{\mathrm{b}} p<0.01 ;{ }^{\mathrm{c}} p<0.001$ compared with untreated Wisis shown in parentheses.

tar group.

${ }^{\mathrm{d}} p<0.05 ;{ }^{\mathrm{e}} p<0.001$ compared with untreated GK group

Table 2. Total beta-cell mass and pancreatic insulin content of 4-day-old Wistar, W/n0-STZ, GK and GK/n0-STZ rat neonates

\begin{tabular}{|c|c|c|c|c|c|c|}
\hline \multirow[t]{2}{*}{ rats } & \multicolumn{2}{|c|}{ Pancreatic insulin } & \multirow{2}{*}{$\begin{array}{l}\text { \% Beta-cells } \\
\text { in pancreas }\end{array}$} & \multicolumn{2}{|l|}{ Beta-cell mass } & \multirow{2}{*}{$\begin{array}{l}\text { Insulin content/ } \\
\text { beta-cell mass } \\
(\mu \mathrm{g} / \mathrm{mg})\end{array}$} \\
\hline & (ug/pancreas) & $(\mu \mathrm{g} / \mathrm{g})$ & & 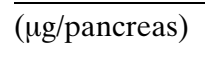 & $(\mu \mathrm{g} / \mathrm{g}$ body wt) & \\
\hline Wistar & $\begin{array}{l}17.8 \pm 0.9 \\
(11)\end{array}$ & $\begin{array}{l}734 \pm 58 \\
(11)\end{array}$ & $\begin{array}{l}2.91 \pm 0.40 \\
(4)\end{array}$ & $\begin{array}{l}590 \pm 80 \\
(4)\end{array}$ & $\begin{array}{l}63.3 \pm 7.1 \\
(4)\end{array}$ & $\begin{array}{l}31 \pm 9 \\
(3)\end{array}$ \\
\hline W/n0-STZ & $\begin{array}{l}0.18 \pm 0.02^{c} \\
(13)\end{array}$ & $\begin{array}{l}8.0 \pm 0.8^{c} \\
(13)\end{array}$ & $\begin{array}{l}0.33 \pm 0.02^{\mathrm{c}} \\
(8)\end{array}$ & $\begin{array}{l}67 \pm 8^{c} \\
(8)\end{array}$ & $\begin{array}{l}7.5 \pm 0.7^{\mathrm{c}} \\
(8)\end{array}$ & $\begin{array}{l}2.3 \pm 0.4^{\mathrm{a}} \\
(4)\end{array}$ \\
\hline GK/n0-STZ & $\begin{array}{l}0.11 \pm 0.01^{\mathrm{e}} \\
(16)\end{array}$ & $\begin{array}{l}8.2 \pm 0.8^{\mathrm{e}} \\
(16)\end{array}$ & $\begin{array}{l}0.18 \pm 0.03^{\mathrm{e}} \\
(4)\end{array}$ & $\begin{array}{l}26 \pm 4^{e} \\
(4)\end{array}$ & $\begin{array}{l}3.3 \pm 0.6^{\mathrm{e}} \\
(4)\end{array}$ & $\begin{array}{l}3.9 \pm 0.2^{\mathrm{e}} \\
(4)\end{array}$ \\
\hline
\end{tabular}

Values are expressed as means \pm SEM. The number of animals is shown in parentheses.

All animals were in non-fasted state.

The pancreatic insulin stores in Wistar and GK rats treated by STZ were greatly decreased $(p<0.001)$ in the two groups compared with the untreated Wistar and GK groups $(1 \%$ and $2 \%$ of the corresponding control values, respectively) (Table 2).

The evaluation of the total beta-cell mass carried out by morphometry showed that there was a large restriction $(p<0.001)$ of the beta-cell mass in the STZ-treated Wistar and GK rats with values representing only $11 \%$ and $12 \%$ of those in the corresponding control beta-cell masses, respectively (Table 2). When $\mathrm{W} / \mathrm{n} 0-\mathrm{STZ}$ and $\mathrm{GK} / \mathrm{n} 0-\mathrm{STZ}$ groups were compared, the $\mathrm{GK} / \mathrm{n} 0-\mathrm{STZ}$ beta-cell mass was found to be about $40 \%$ of that of $\mathrm{W} / \mathrm{n} 0-\mathrm{STZ}$ rats. The mean insulin content for each beta cell was decreased $(p<0.001)$ in the $\mathrm{W} / \mathrm{n} 0-\mathrm{STZ}$ and $\mathrm{GK} / \mathrm{n} 0$ STZ newborns (by $92 \%$ and $85 \%$, respectively) compared with the corresponding untreated groups (Table 2).

The BrdU labelling index of the beta cells was determined by double immunocytochemical staining for insulin and BrdU. In both STZ-treated Wistar and GK groups, the index was higher $(p<0.01)$ than in untreated control groups (Fig.1). No statistically significant difference was observed when comparing BrdU beta-cell labelling indices in W/n0-STZ and $\mathrm{GK} / \mathrm{n} 0-\mathrm{STZ}$ groups.

The rate of beta-cell apoptosis was very low in both Wistar and GK pancreases and there was no statistically significant difference between these two groups $(0.55 \pm 0.05 \%, n=4$, in the Wistar group and $0.64 \pm 0.06 \%, n=3$, in the GK group).

Characteristics of the 7-day-old GK/nO-STZ and W/ $n 0-S T Z$ rats. The plasma glucose concentrations in $\mathrm{W} / \mathrm{n} 0-\mathrm{STZ}$ rats were still higher $(p<0.001)$ than those in normal rats 6 days after treatment with STZ but were decreased $(p<0.001)$ to low values compared with those in 4-day-old n0-STZ rats. In contrast, the basal plasma glucose concentrations were similar in 7-day-old GK/n0-STZ rats and GK rats and were no longer statistically significantly different from those in 7-day-old non-diabetic Wistar rats (Table 1). It is also remarkable that basal plasma glucose 


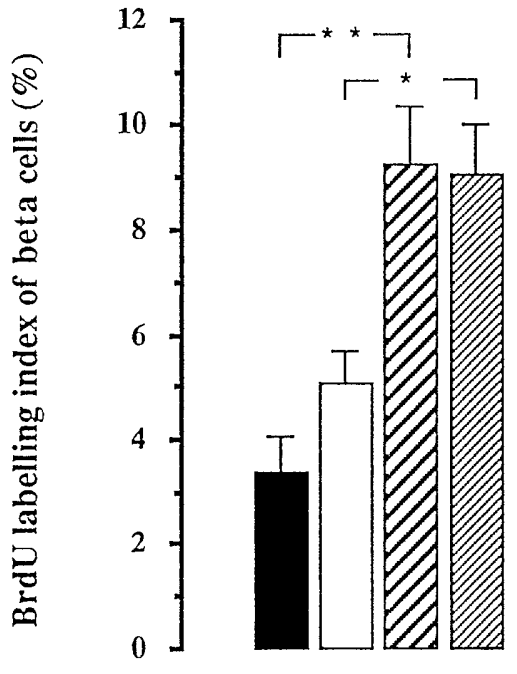

day 4

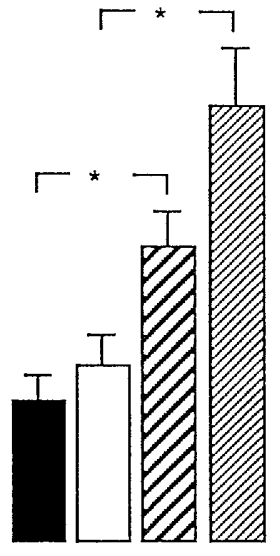

day 7
Fig. 1. BrdU labelling index of beta cells in 4-day-old and 7-

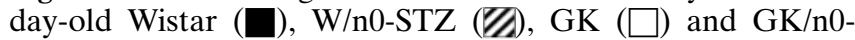
STZ (שTAS) rats $(\% \pm \mathrm{SEM}) . * p<0.05, * * p<0.01$ compared with the age-matched controls

concentrations of 7-day-old untreated GK rats were increased $(p<0.001)$ compared with those on day 4 (Table 1).

Light microscopy examination of the pancreatic sections of the Wistar and GK neonates treated previously by STZ, showed that insulin-immunoreactive cells were still scanty compared with Wistar and GK control groups (Fig.2). They were, however, more abundant than in the pancreases of the 4-day-old W/ n0-STZ and GK/n0-STZ animals. In both STZ-treated groups, they were well granulated and were located either in the central part of the islets or found isolated or in small clusters randomly scattered throughout the acinar tissue. Duct-lining buds with beta cells were still seen in the 7-day-old GK/n0$\mathrm{STZ}$ and $\mathrm{W} / \mathrm{n} 0-\mathrm{STZ}$ rats as well as in their age-matched controls.
The pancreatic insulin store in the $\mathrm{W} / \mathrm{n} 0-\mathrm{STZ}$ rats was $7 \%$ compared with the corresponding stores in the control rats and their total beta-cell mass was $27 \%$ of that in the controls. In the GK/n0-STZ group the pancreatic insulin store and the total beta-cell mass represented $5 \%$ and $23 \%$ of that in the untreated GK group (Table 3). Finally, the mean insulin content per beta cell was decreased $(p<0.001)$ (by $65 \%)$ in W/n0-STZ rats compared with that in Wistar rats and (by $72 \%$ ) in GK/n0-STZ rats compared with GK rats (Table 3). From these data, we have extrapolated the growth rate of the beta-cell compartment in each group (Fig. 3). The fractional increase between day 4 and day 7 (per cent increase of total beta-cell mass) was eightfold higher in the $\mathrm{W} / \mathrm{n} 0$-STZ rats than in the Wistar rats $(200 \%$ and $25 \%$ beta-cell mass increases, respectively). In GK groups, the difference in this tractional increase between the rats treated with STZ and the untreated rats was more pronounced being extremely small $(5 \%)$ in untreated rats and 18 -fold higher in $\mathrm{GK} / \mathrm{n} 0-\mathrm{STZ}$ rats ( $92 \%$ increase).

The BrdU labelling indices of the beta cells were similar in the 7-day-old W/n0-STZ and GK/n0-STZ rats and higher $(p<0.05)$ than those in Wistar and GK rats (Fig. 1).

We also evaluated the BrdU labelling index of the duct cells in the 7-day-old W/n0-STZ and GK/n0STZ groups. The replication rate of the duct cells was higher $(p<0.05)$ in $\mathrm{W} / \mathrm{n} 0-\mathrm{STZ}$ rats than in $\mathrm{GK} /$ n0-STZ rats being $5.24 \pm 0.56 \%(n=3)$ in the $\mathrm{W} / \mathrm{n} 0$ STZ group and $2.71 \pm 0.53 \%(n=3)$ in the GK/n0STZ group. Moreover, in the GK/n0-STZ rats, the number of beta-cell clusters associated with the ducts was lower $(p<0.01) \quad(0.33 \pm 0.04$ beta-cell clusters $\cdot 100$ duct cells ${ }^{-1} \cdot$ pancreas $\left.^{-1}\right)$ compared with that in the W/n0-STZ rats $(0.54 \pm 0.05$ beta-cell clusters $\cdot 100$ duct cells $^{-1} \cdot$ pancreas $\left.^{-1}\right)$. The number of single beta cells associated with the ducts was not statistically significantly different in the W/n0-STZ and $\mathrm{GK} / \mathrm{n} 0-\mathrm{STZ}$ rats $(1.1 \pm 0.38$ single beta cells $\cdot 100$ duct cells ${ }^{-1} \cdot$ pancreas $^{-1}$ in the GK/n0-STZ rats and

Table 3. Total beta-cell mass and pancreatic insulin content of 7-day-old Wistar, W/n0-STZ, GK and GK/n0-STZ rat neonates

\begin{tabular}{|c|c|c|c|c|c|c|c|}
\hline \multirow[t]{2}{*}{ rats } & \multicolumn{2}{|c|}{ Pancreatic insulin } & \multirow{2}{*}{$\begin{array}{l}\text { \% Beta-cells } \\
\text { in pancreas }\end{array}$} & \multicolumn{2}{|l|}{ Beta-cell mass } & \multirow{2}{*}{$\begin{array}{l}\text { Insulin content/ } \\
\text { beta-cell mass } \\
(\mu \mathrm{g} / \mathrm{mg})\end{array}$} & \multirow{2}{*}{$\begin{array}{l}\text { Beta-cell area } \\
\left(\mu \mathrm{m}^{2}\right)\end{array}$} \\
\hline & ( $\mu \mathrm{g} /$ pancreas) & $(\mu \mathrm{g} / \mathrm{g})$ & & 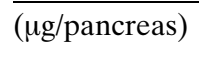 & ( $\mu \mathrm{g} / \mathrm{g}$ body wt) & & \\
\hline Wistar & $\begin{array}{l}19.8 \pm 0.1 \\
(13)\end{array}$ & $\begin{array}{l}552 \pm 33 \\
(13)\end{array}$ & $\begin{array}{l}2.45 \pm 0.12 \\
(4)\end{array}$ & $\begin{array}{l}740 \pm 60 \\
(4)\end{array}$ & $\begin{array}{l}50.9 \pm 2.5 \\
(4)\end{array}$ & $\begin{array}{l}24.6 \pm 1.6 \\
(4)\end{array}$ & $\begin{array}{l}97 \pm 5 \\
(28)\end{array}$ \\
\hline W/n0-STZ & $\begin{array}{l}1.4 \pm 0.1^{\mathrm{c}} \\
(10)\end{array}$ & $\begin{array}{l}40 \pm 4^{\mathrm{c}} \\
(10)\end{array}$ & $\begin{array}{l}0.61 \pm 0.07^{\mathrm{c}} \\
(8)\end{array}$ & $\begin{array}{l}200 \pm 20^{c} \\
(8)\end{array}$ & $\begin{array}{l}13.8 \pm 1.7^{\mathrm{c}} \\
(8)\end{array}$ & $\begin{array}{l}8.7 \pm 0.6^{c} \\
(4)\end{array}$ & $\begin{array}{l}112 \pm 8 \\
(41)\end{array}$ \\
\hline GK/n0-STZ & $\begin{array}{l}0.33 \pm 0.06^{\mathrm{e}} \\
(10)\end{array}$ & $\begin{array}{l}22 \pm 5^{\mathrm{e}} \\
(10)\end{array}$ & $\begin{array}{l}0.28 \pm 0.03^{\mathrm{e}} \\
(4)\end{array}$ & $\begin{array}{l}50 \pm 7^{e} \\
(4)\end{array}$ & $\begin{array}{l}8.3 \pm 1.5^{\mathrm{e}} \\
(4)\end{array}$ & $\begin{array}{l}8.1 \pm 1.5^{\mathrm{e}} \\
(4)\end{array}$ & $\begin{array}{l}102 \pm 7 \\
(21)\end{array}$ \\
\hline
\end{tabular}

Values are expressed as means \pm SEM. The number of animals is shown in parentheses.

All animals were in non-fasted state.

${ }^{\mathrm{c}} p<0.001$ compared with untreated Wistar group. ${ }^{\mathrm{e}} p<0.001$ compared with untreated GK group 

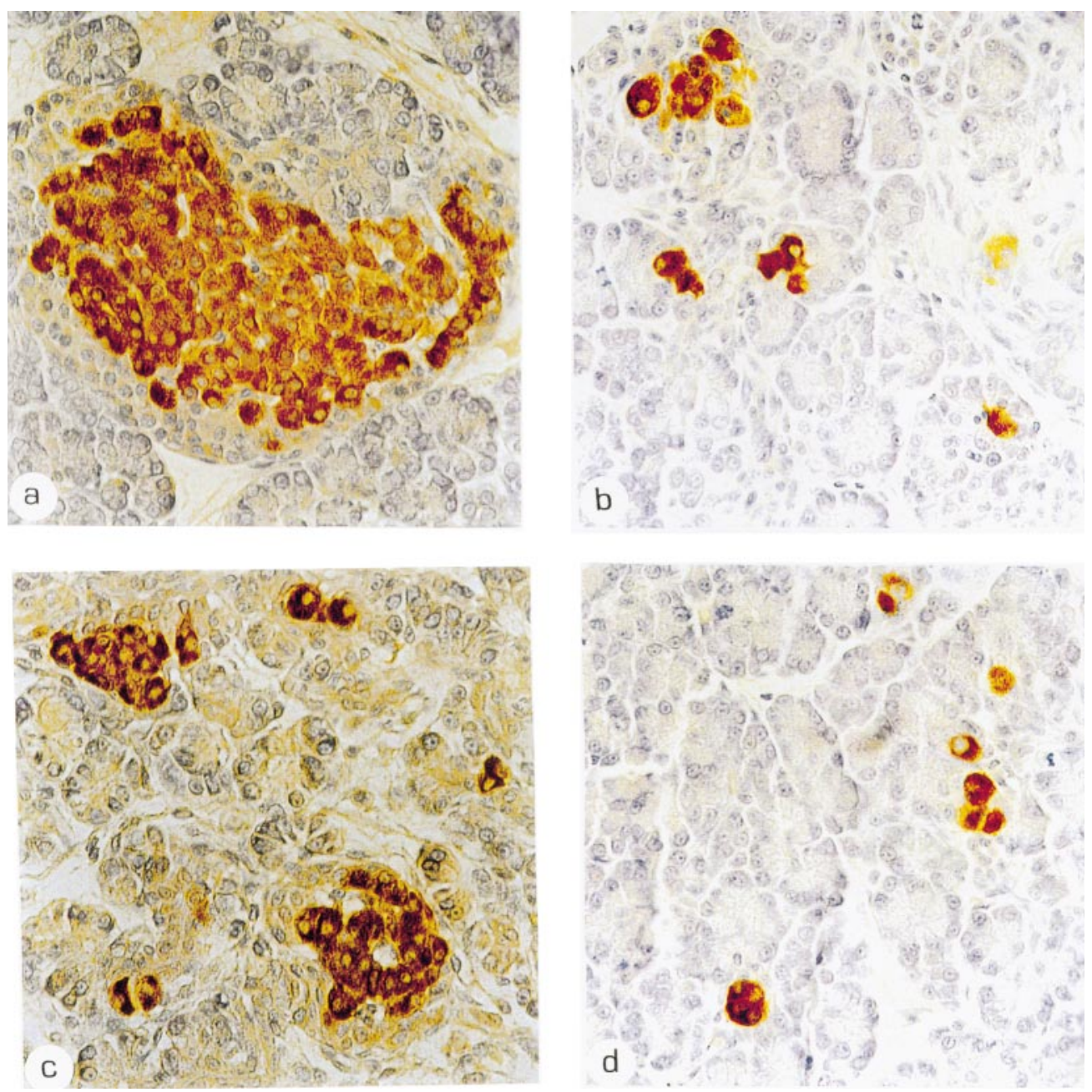

Fig. 2.a-d Immunostaining for pancreatic insulin in 7-day-old Wistar (a), W/n0-STZ (b), GK (c) and GK/n0-STZ (d) rats (magnification $\times 400)$

$0.48 \pm 0.11$ single beta-cells $\cdot 100$ duct cells ${ }^{-1} \cdot$ pancre$\mathrm{as}^{-1}$ in the $\mathrm{W} / \mathrm{n} 0-\mathrm{STZ}$ rats).

Beta-cell apoptosis was slightly lower but not statistically significantly different in the GK rats compared with Wistar rats matched with them for age $(0.5 \pm$ $0.1 \%, n=3$ and $0.8 \pm 0.1 \%, n=5$, respectively).

The individual cross-sectional area of the beta cells was not statistically significantly different in the Wistar, GK, W/n0-STZ and GK/n0-STZ pancreases (Table 3). This indicates that all changes observed in the total beta-cell mass of the four groups studied can be ascribed mostly to the changes in beta-cell number (and not to cell hypertrophy or hypotrophy).

\section{Discussion}

We and others have shown previously that treating Wistar rats with STZ on the day of birth led to a se-

vere reduction in total beta-cell mass compared with that in normal Wistar rats [7, 8]. After such insult, the corresponding normal beta-cell mass was partially regained during the first weeks after birth $[9,10]$.

Here we show that the beta cells of the GK rat, a spontaneous model of Type II diabetes with reduced beta-cell mass [2], are able to regenerate after their subtotal destruction by STZ. It is important to notice that STZ exerted a toxic effect on beta cells similar in the GK rats and in the Wistar rats, as 3 days after treatment with STZ the beta-cell mass was reduced by $90 \%$ in both $\mathrm{GK} / \mathrm{n} 0-\mathrm{STZ}$ and $\mathrm{W} / \mathrm{n} 0-\mathrm{STZ}$ groups. Our data obtained on day 4 and day 7 indicate that beta cells were able to regenerate. The beta-cell regeneration was, however, limited in both groups.

Concerning the basal biological characteristics of GK rats, we have recently reported that despite their decreased basal insulin concentration and reduced total beta-cell mass, untreated GK newborns exhibited normal glycaemia compared with Wistar newborns of the same age [2]. We found that after treatment with STZ the changes in these variables were strikingly different between GK and Wistar rats. Although in Wistar rats, STZ treatment caused a severe hyperglycaemia in 4 and 7-day-old animals, GK/n0- 

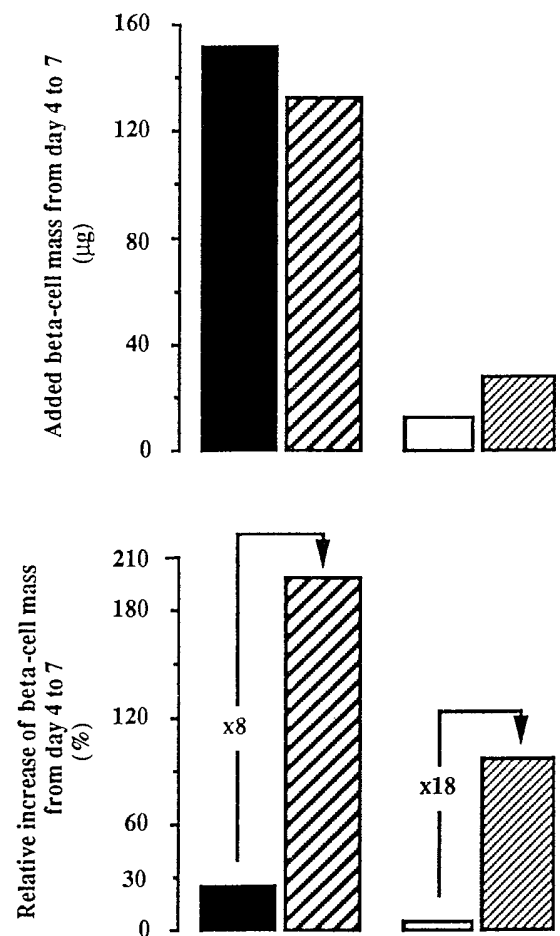

Fig. 3. Increase of beta-cell mass between day 4 and 7 in Wistar

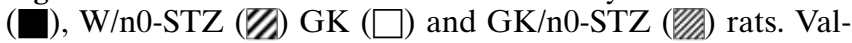
ues are expressed as beta-cell mass added from day 4 to 7 (upper panel) or as percentage of increase of total beta-cell mass from day 4 to 7 (lower panel)

STZ rats paradoxically showed less severe hyperglycaemia on day 4 and had regained normal glycaemia on day 7 after birth. This was although in 7-day-old $\mathrm{GK} / \mathrm{n} 0-\mathrm{STZ}$ rats, the beta-cell mass was only $25 \%$ of that in W/n0-STZ rat and only $8 \%$ of that in the non-diabetic Wistar rat.

Our results show that the growth of beta cells from 4 to 7 days after birth is such as to increase the betacell mass when expressed in absolute terms (added beta-cell mass from 4 to 7 days) less in the $\mathrm{GK} / \mathrm{n} 0$ STZ group than in the W/n0-STZ group (Fig. 3, upper panel). The beta-cell growth expressed as the fractional increase between day 4 and 7 (per cent increase of total beta-cell mass) was $92 \%$ in $\mathrm{GK} / \mathrm{n} 0-\mathrm{STZ}$ rats and $200 \%$ in W/n0-STZ rats (Fig. 3, lower panel). It is, however, remarkable that compared with the relative growth of beta cells in untreated GK rats $(5 \%$ during days 4-7), the relative increase of beta-cell mass in GK/n0-STZ rats is higher (being 18-fold more important than that in the untreated GK group during the same days 4-7 period) reflecting their capacity to partially regenerate (Fig. 3, lower panel).

In interpreting these data, it should be noted that our calculation of total beta-cell mass relies on the value of the total pancreatic weight and the total pancreas weight at day 4 and the growth rate of pancreatic tissue from day 4 to day 7 were very different in the Wistar and the GK groups. From the data in Table 1 it can be calculated that the per cent increase of total pancreas mass was $77 \%$ in the Wistar group and only $18 \%$ in the GK group. There was also a large difference concerning this variable between the $\mathrm{W} /$ n0-STZ group (57\% increase) and GK/n0-STZ group $(23 \%)$. Therefore to avoid any bias introduced by the difference of the total pancreatic growth in the evaluation of the beta-cell population, we have also compared the values of the ratio of the total insulin-immunoreactive area over the whole area of the pancreatic sections (\% beta cells per pancreas) in the GK/ n0-STZ and the W/n0-STZ groups from day 4 to 7 after birth: the fractional increase of \% beta cells during this period was $85 \%$ in the $\mathrm{W} / \mathrm{n} 0-\mathrm{STZ}$ group compared with $56 \%$ in the $\mathrm{GK} / \mathrm{n} 0-\mathrm{STZ}$ group whereas it was slightly decreased in both untreated $\mathrm{W}$ and GK groups (by $15 \%$ and $11 \%$, respectively). Such a comparison is consistent with the conclusion that after STZ insult the regeneration capacity is still effective in GK neonates, although lower than in W/n0-STZ neonates.

We found beta-cell replication was not changed in 4-day-old or 7-day-old untreated GK rats compared with age matched Wistar rats. The BrdU labelling index of beta cells was increased in both GK/n0-STZ and $\mathrm{W} / \mathrm{n} 0-\mathrm{STZ}$ groups compared with the age matched untreated Wistar and GK groups.

Because apoptosis is rapid (1-3 h) and it is rarely detectable in slowly renewed tissues such as beta cells, quantification of beta-cell apoptosis should be viewed with caution. Using the TUNEL method and the morphological characteristics of apoptotic cells (see Materials and methods), we were not able to detect any statistically significant difference between untreated Wistar and GK groups on days 4 and 7 after birth. Interestingly apoptotic nuclei were also found in the exocrine pancreas and their frequency was increased in the exocrine pancreas of GK rats at day 4 and 7 compared with age-matched Wistar rats. Our apoptosis data in neonatal beta cells were lower than those found in another study [6]. This difference is probably mainly related to the difference in the methods used.

There is strong evidence that beta-cell growth in mammals is the result of two major processes: neogenesis (or differentiation of beta cells from precursor cells) or replication of pre-existing beta cells or both [3-5]. In the developing rodent pancreas, the beta-cell mass initially expands from differentiation of new beta cells but by the late fetal stage the differentiated beta cells replicate $[5,16]$. Neogenesis still continues, however, to participate to the expansion of beta-cell mass during early post natal life [3]. Taken as a whole, our results suggest that the decreased beta-cell mass in GK neonates in the basal situation is not related to defective replication and apoptosis capacities of the beta cells but is potentially attributable to defective beta-cell neogenesis. Alternatively, 
since endocrine cytodifferentiation in the pancreas involves circulating and locally produced factors [3], the possibility that regulatory factors of beta-cell growth could be deficient in the GK pancreas during the neonatal period cannot be eliminated. Since we know that overall pancreas growth is retarded in GK rats compared with the age-matched Wistar rats, the possibility that the production/action of some of these factors could be impaired in the neonatal GK rat cannot be excluded. In addition, the sharply decreased plasma insulin concentration in GK neonates $[2,17]$ may also contribute to the alteration of differentiation of new beta cells from precursor cells since insulin is recognized to stimulate growth and differentiation of several cell types [18]. Insulin has growth promoting actions on fetal hepatocytes in primary culture [19]. Fetal rat pancreas explanted in vitro with added insulin got a greater beta-cell volume and a greater insulin content than those grown without added insulin [20]. We have recently reported that treatment with insulin in vivo enhances beta-cell growth in the pancreas of STZtreated newborn rats, with a preferential effect on the neogenesis of beta cells from precursors cells [10]. Finally, since the GK rats exhibited an overall growth retardation after birth, we cannot exclude that the growth hormone plasma concentrations are abnormal. In a number of tissues including the fetal rat islets, growth hormone induces the local production of IGFs [21, 22]. The effectiveness of insulinlike-growth factors on islet cell proliferation has been largely shown in the perinatal rat [23-26] and the human fetus [27]. Insulin-like growth factor1 has also been suggested to stimulate cellular differentiation rather than proliferation of ductular cells in the regenerating rat pancreas [28].

In conclusion we studied the GK rat, a genetic model of Type II diabetes with reduced beta-cell mass which is observed as early as in fetal life and maintained in adults. Our results show firstly, that replication and apoptosis rates of beta cells in GK neonates in vivo are not changed compared with non-diabetic Wistar neonates. Secondly, the regeneration of beta cells after STZ insult is still effective in GK neonates and the regeneration response is even more important than in non-diabetic Wistar neonates in relative terms. Thirdly, the replication from surviving differentiated beta cells is increased after STZ insult in GK neonates as in W neonates, and represents an important component of the beta-cell regeneration process in both. Taken as a whole these data are consistent with the assumption that the reduced beta-cell mass as observed in the adult GK rat putatively reflects a limitation of beta-cell neogenesis during early fetal life. It is conceivable that some genes among the set causing Type II diabetes in the GK rat $[29,30]$ belong to the subset of genes controlling the capacity for early beta-cell neogenesis.
Acknowledgements. We are grateful to D. Bailbé for expert assistance with the GK rat breeding. This work was partly supported by grants from the Lilly-France Institute (contrat de recherche en Diabétologie ALFEDIAM/LILLY 1994) and the Foundation of France (Comité Recherche Médicale, 1998). J. Movassat received a doctoral fellowship from the french national ministry of higher education (Ministère de l'Education Nationale, de l'Enseignement Supérieur et de la Recherche, allocation de recherche $\mathrm{n}^{\circ} 14314$ ) and is a recipient of an ALFEDIAM postdoctoral fellowship (1998).

\section{References}

1. Klöppel G, Löhr M, Hablich K, Oberholzer M, Heitz PU (1985) Islet pathology and pathogenesis of type I and type II diabetes revisited. Surv Synth Pathol Res 4: 110-125

2. Movassat J, Saulnier C, Serradas P, Portha B (1997) Impaired development of pancreatic $\beta$-cell mass is a primary event during the progression to diabetes in the GK rat. Diabetologia 40: 916-925

3. Bouwens L, Klöppel G (1996) Islet cell neogenesis in the pancreas. Virchows Arch 427: 553-560

4. Bonner-Weir S, Smith FE (1994) Islet cell growth and the growth factors involved. Trends Endocrinol Metab 5: 60-64

5. Swenne I (1992) Pancreatic Beta-cell growth and diabetes mellitus. Diabetologia 35: 193-201

6. Scaglia L, Cahill CJ, Finegood DT, Bonner-Weir S (1997) Apoptosis participates in the remodeling of the endocrine pancreas in the neonatal rat. Endocrinology 138: 1736-1741

7. Portha B, Levacher C, Picon L, Rosselin G (1974) Diabetogenic effect of streptozotocin in the rat during the perinatal period. Diabetes 23: 889-895

8. Bonner-Weir S, Trent DF, Honey RN, Weir GC (1981) Responses of neonatal rat islets to streptozotocin: limited Bcell regeneration and hyperglycemia. Diabetes 30: 64-69

9. Wang RN, Bouwens L, Klöppel G (1994) Beta-cell proliferation in normal and streptozotocin-treated newborn rats: site, dynamics and capacity. Diabetologia 37: 1088-1096

10. Movassat J, Saulnier C, Portha B (1997) Insulin administration enhances growth of the $\beta$-cell mass in streptozotocintreated newborn rat. Diabetes 46: 1445-1452

11. Portha B, Serradas P, Bailbé D, Suzuki K, Goto Y, Giroix MH (1991) $\beta$-cell insensitivity to glucose in the GK rat, a spontaneous non obese model for type II diabetes. Diabetes 40: 486-491

12. Goto Y, Kakizaki M, Masaki N (1975) Spontaneous diabetes produced by repeated selective breeding of normal Wistar rats. Proc Jpn Acad 51: 80-85

13. Michel C, Chariot J, Souchard M, Roze C (1982) Modifications of the endocrine pancreas in rats after ethionine destruction of acini. Cell Mol Biol 28: 135-148

14. Kontogeorgos G, Kovacs K (1995) Apoptosis in endocrine glands. Endocrine Pathology 6: 257-265

15. Montana E, Bonner-Weir S, Weir GC (1994) Transplanted Beta cell response to increased metabolic demand. Changes in Beta cell replication and mass. J Clin Invest 93: 1577-1582

16. Hellerström C, Andersson A, Swenne I, Welsh M, Welsh N, Sjöholm A (1988) Replication of B cells in the normal and diabetic pancreas. In: Grill V, Efendic S (eds) Pathogenesis of non-insulin dependent diabetes mellitus. Raven Press, New York 79-91

17. Serradas P, Gangnereau MN, Giroix MH, Saulnier C, Portha B (1998) Impaired pancreatic beta cell function in the fetal GK rat. Impact of diabetic inheritance. J Clin Invest 101: 899-904 
18. De Pablo F, Scott AL, Roth J (1990) Insulin and Insulinlike growth factor I in early development: peptides, receptors and biological events. Endocr Rev 11: 558-577

19. Gruppuso PA, Boylan JM, Bienieki TC, Curran TR (1994) Evidence for a direct hepatotrophic role for insulin in the fetal rat: implications for the impared hepatic growth seen in fetal growth retardation. Endocrinology 134: 769-775

20. Mc Evoy RC (1981) Fetal rat pancreas in organ culture. Effect of exogenous insulin on the development of islet cells. Horm Metab Res 13: 5-8

21. Milner RDG, Hill DJ (1984) Fetal growth control: the role of insulin and related peptides. Clin Endocrinol 21: 415-433

22. D'Ercole AJ, Stiles AD, Underwood LE (1984) Tissue concentrations of somatomedin C: further evidence for multiple sites of synthesis and paracrine or autoimmune mechanisms of action. Proc Natl Acad Sci 81: 935-939

23. Swenne I, Hill DJ, Strain AJ, Milner RDG (1987) Growth hormone regulation of somatomedin C/insulin-like growth factor I production and DNA repication in fetal rat islets in tissue culture. Diabetes 36: 288-294

24. Rabinovitch A, Quigley C, Russel T, Patel Y, Mintz DH (1982) Insulin and multiplication stimulating activity (an insulin-like growth factor) stimulate islet $\beta$-cell replication in neonatal rat pancreatic monolayer cultures. Diabetes 31: $160-164$
25. Swenne I, Hill DJ, Strain AJ, Hellerström C (1988) Effects of platelet-derived growth factor and somatomedin $\mathrm{C} / \mathrm{insu}-$ lin-like growth factor I on the DNA replication of fetal rat islets of Langerhans in tissue culture. Endocrinology 122: 214-218

26. Petrik J, Arany E, Mc Donald TJ, Hill DJ (1998) Apoptosis in the pancreatic islet cells of the neonatal rat is associated with a reduced expression of insulin-like growth factor II that may act as a survival factor. Endocrinology 139: 2994-3004

27. Otonkoski T, Knip M, Wong I, Simell O (1988) Effects of growth hormone and insulin-like growth factor I on endocrine function of human fetal islet-like clusters during long-term culture. Diabetes 37: 1678-1783

28. Smith F, Rosen KM, Komaroff LV, Weir GC, Bonner-Weir S (1991) Enhanced insulin-like growth factor I gene expression in regenerating rat pancreas. Proc Natl Acad Sci 88: 6152-6156

29. Gauguier D, Froguel P, Parent V, Bernard C, Bihoreau MT, Portha B, James M, Penicaud L, Lathrop M, Ktorza A (1996) Chromosomal mapping of genetic loci associated with non insulin dependent diabetes in the GK rat. Nat Genet 12: 38-43

30. Galli J, Shen S, Glaser A et al. (1996) Genetic analysis of non-insulin-dependent diabetes mellitus in the GK rat. Nat Genet 12: 33-37 